\title{
From victimhood to hubs of (trans)formation and local agency: Re-imagining poor urban communities
}

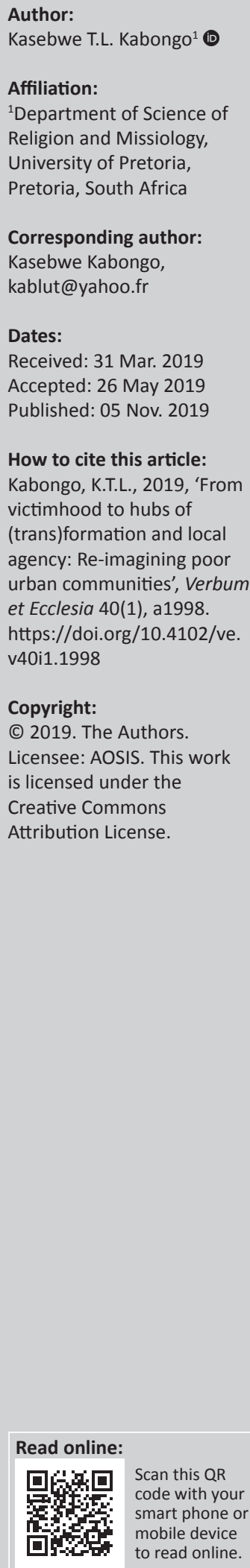

This article was written from the perspective of a black African who has been unfairly subjected to colonialism, apartheid and neo-colonialism. This African is learning to simultaneously blame others for mistakes committed against him and interrogate his own agency in being an answer to his own prayers. He has observed that communities of poverty are usually seen as undesirable. As a consequence of this, most of its residents prefer to move away, if they have the option of doing so. This article explored the concept of thin places as a vehicle to nurture agency amongst people living in communities of poverty such as Soshanguve. It uses the narrative approach of storytelling to recount particular past events and present ones as a tool to cultivate a 'can-do attitude' in ordinary people. The goal is to raise agents of hope who will bring good news to their neighbours and anybody else, using biblical principles as a critical tool in their toolkit. Communities of poverty are usually seen as undesirable. As a consequence, most of its residents prefer to move out, if they have the choice to do so. This article reflects on the efforts of a missional team, InnerCHANGE, to help residents of the township of Soshanguve migrate from a victim mentality to become agents of their own hope. It uses a theology of place that alludes to concepts of thin places which challenges ordinary people to become participants in the flourishing of lives around them. A reflection on agency influenced by the Black Consciousness Movement and other African scholars gave context, meaning and relevance to such a theology of place. Stories of agency from Africa are remembered and retold to inspire ordinary people. Some of the latter have taken to heart these inspirational stories and have been transformed into agents. This article calls such people transformation agents. A conclusion was made that the Church needs to continue playing its prophetic role in society. Such a role could entail reminding people of existing assets they may have such as stories told around them of people who defied the normal victim mentality seen in poor communities and actively built thin places around them.

Intradisciplinary and/or interdisciplinary implications: This article was based on the field of missiology. It engaged historical facts (history) in a way that could nurture and develop agency in ordinary people. It challenges a general apathy towards community involvement found within the body of Christ located in South African communities of poverty.

Keywords: agency; community; flourishing life; neighbour; storytelling; transformation; thin places.

\section{Introduction}

Communities of poverty are usually seen as undesirable. As a consequence of this, most of its residents prefer to move away, if they have the choice to do so. Some of its residents feel trapped in an undesirable place where they live because of a lack of choice. InnerCHANGE, a missional team, serves in the township ${ }^{1}$ of Soshanguve. It is exploring a theology of place that could be articulated in a way that could develop and nurture agency from within. Reality and contextuality demand a theology of place, which can be defined as an appreciation for the theological significance of specific geographic locations. This implies, first of all, that the church must be incarnated in each particular place. Conradie (2009:3) says that 'a theology of place has deep roots in the Jewish-Christian tradition. The core themes of the Christian faith are closely tied up with a theology of place'. The latter seeks to empower people to be builders of thin places where they reside. Incarnation is a key paradigm for this process of developing agency from the inside out and understanding thin places. Fitch (2016:401) argues that the Great Commission is fulfilled

1.In South Africa, a township (also called a location) refers to the often underdeveloped, racially segregated urban areas that, from the late 19th century until 1994, were reserved for non-whites. They were usually built on the periphery of towns and cities. The township of Soshanguve was a location for black people only. It is located 40 kilometres north of the city of Pretoria. 
when missio Dei and incarnation come together in one concrete place'. Thin places are a spiritual concept that describes 'the veil between this world and the eternal world as thin' (Thin Places Tour 2018). In such places, individuals can walk in two worlds, such as the physical world as we know it and the spiritual realm (Thin Places Tour 2018). Huckins and Yackley (2012:7) stress that '[l]iving in the thin places' requires new eyes so that we can proactively 'participate in God's healing work in our world'.

From an African perspective, Ntumba (quoted by Mwambazambi \& Banza 2014:7) marries theology of place and thin places when he stresses that 'a theology of place should be well articulated and preached to all' Africans so that, as citizens, they could learn to be in charge of 'their countries starting from their contexts of life and influence'. Arguing along the same lines, the Ugandan artist Bobi Wine (2017) states that all residents of African communities 'must learn to come together to fight for the political, economic, social and financial freedom for all'. The Congolese reggae musician Muhindo (2018) adds his voice in inviting all Africans to live in solidarity with one another to firmly stand against poverty, war, suffering, rape and abduction. A theology of place that trains residents of communities of poverty to view their space as thin places has the potential to generate stories of hope from the inside out. Katongole (2017:21) argues that there has been a deficit in stories of hope in Africa. According to him, there are many reasons for this deficit. One of them is:

[T]he fact that Christian theology and practice have tended to readily and uncritically surrender the diagnosis and prescription for what is going on to the secular disciplines of politics, economics, and sociology. (Katongole 2017:21)

In communities of poverty such as Soshanguve, the 'Christian practice and theology' tends to be 'framed primarily in spiritual terms, which tends to reduce theological discussions of hope to nothing more than forms of private spiritual encouragements, motivations, and consolations' (Katongole 2017:21).

This reality of dualism is challenging InnerCHANGE to focus its efforts on helping its staff and community members to view their neighbourhoods as thin places. These are places where their faith is tightly connected to a sense of duty to participate in society-building. It uses the narrative approach of storytelling to ask the question: How can storytelling equip ordinary people to be agents of their own hope? This narrative approach focuses on the spoken recounting of particular past events that happened' (Andrews, Squire \& Tamboukou 2013) as a tool to nurture and develop agency in people. The advantage of narrative research is that it 'allows people to effectively make sense of their world - and communicate these meanings - by constructing, reconstructing and narrating stories' (Polit \& Beck 2008:236). Through it, 'individuals construct stories when they wish to understand specific events and situations that require linking the inner world of desire and motive to an external world of observable actions' (Polit \& Beck 2008:236).

The investment into local agency is inspired by Jeremiah 29:7, which encourages all children of God to actively seek the peace and prosperity of the neighbourhood, township or city in which they live. The hope is to see ordinary people seek a joyful and flourishing life around them in solidarity with one another. InnerCHANGE seeks to disciple such people, using biblical principles. Niemandt (2016:1) stresses that 'discipleship must be an invitation to joyful and flourishing life'. Volf and Croasmun (2019) define 'flourishing life' as:

The good toward which humans are meant to strive. It names not so much any number of things we desire, but the ultimate goal of our striving along with the values that determine what is truly worth desiring. We use the term more or less interchangeably with 'true life', 'good life', 'life worth living', 'human fullness', 'life that truly is life' and more. (p. 13)

The concept of a flourishing life is meaningful in the context of the poor communities InnerCHANGE works with because it holistically affirms life. In its document Together Towards Life, the World Council of Churches states:

Affirming life in all its fullness is Jesus Christ's ultimate concern and mission (John 10:10). We believe in God, the Holy Spirit, the Life-giver, who sustains and empowers life and renews the whole creation (Genesis 2:7; John 3:8). (Keum 2013:8)

Volf (2015:2) goes further in expanding our boundaries when he points out that the 'vision of flourishing life is found in Christianity as well as other world religions. It is essential to individual thriving and global common good'. Additionally, Volf comments that 'world religions shape the lives of more than two-thirds of the world population' (Volf 2015:63-64). Van der Merwe (2015) concurs with him in stating that:

$[R]$ eligion provides people with a sense of meaning and purpose, a way to cope with the many crises of life and direction on the relationship between individuals, communities and creation. (p. 313)

This is why InnerCHANGE has endeavoured to tell stories - for ordinary people to learn to have new eyes for the reality around them and to see their context as a thin place where their lives and that of others would flourish. The end in mind of this storytelling narrative is to attempt in a small way to equip people as agents of hope. Many of these people feel disarmed and helpless as they face overwhelming realities such as poverty, violence, crime and lack of fairness in society.

\section{Reflection on agency}

Steve Biko and the Black Consciousness Movement inspired this reflection. Biko (2007:156) stresses that people need to 'rally together with their fellows in order to bring transformation' and build the kind of society they want to become. He also points out that people's 'self-examination and determination to bring a humane society in South Africa'. 
In his appraisal of black consciousness, the urban theologian Stephan de Beer (2008) believes that the Black Consciousness Movement is:

[A] philosophy of communal solidarity among an oppressed people. Although Steve Biko's premise was blackness as experienced in South Africa, he deliberately sought to situate his work in a more universal humanist framework, identifying it as part of a global movement of solidarity with all oppressed people. (p. 172)

This is that they could be agents of the kind of society they desire (De Beer 2008:172). De Beer (2008) continues by stressing that the work of:

$[F]$ ostering black consciousness should continue, calling blacks back to solidarity with their communities of origin, as well as black people who are still living with the scars of stolen dignity to a discovery of their own humanity, giftedness and agency. (p. 174)

The church could be a catalyst of such a task. Scott Bessenecker (cited in Hayes 2006) rightly says that, 'Jesus calls the church to attach itself uncomfortably to marginalised people and use its hands to do something that would empower them'.

The church serving in communities of poverty can participate in the collective imagination of a better community and help implement a vision that will come out of the imagination exercise. All community stakeholders should be brought together to articulate 'ways in which they can contribute to making such a vision' a reality (De Beer 2008:6). The church could then recruit 'sensitive designers, planners, and bureaucrats from within the community in order to integrate diverse visions into one coherent, cohesive vision for a particular neighbourhood' (De Beer 2016:6). Katongole (2017:205) believes that 'Christianity needs to be grounded on the African soil'. It should be an instrument of hope for the poor in helping them to be agents of the resolution of their 'everyday problems' (Katongole 2017:205).

In reflecting on their experience as mission workers in communities of poverty, Huckins and Yackley (2012:6) state that 'real life and real transformation happen in the context of intentional practices and authentic relationships' that lead people to be agents of the kind in society they desire. This is in line with Biko's thinking that ' $[t]$ he most powerful weapon in the hand of the oppressor is the mind of the oppressed' (Biko 2007). John Henrik Clarke (1991:57) argues along the same lines: 'To control a people you must first control what they think about themselves and how they regard themselves and how they regard their history and culture'. In his reflection on black African Christians who were persecuted because of their prophetic witnessing, Katongole (2017:xiii) stresses that their agency and activism was born in and through the experience of suffering and social dislocation'. $\mathrm{He}$ also points out the high capacity of these faith activists to embrace, hold and transform their 'experience of personal and communal suffering and tragedy into energy, commitment, and advocacy for non-violent alternatives'.
Many of these faith activists became martyrs. According to Katongole (2017):

$[M]$ artyrs provide the most decisive and clearest example of hope, and their memory is a form of resistance against cheap hope that struggles to transform the structures of violence, poverty, and marginalisation into an excess of love. (p. xix)

Talking as a black person, I would like to stress that: [F]reeing ourselves from the inferiority complex by systems that apportioned value and human dignity according to a colour code remains the most important stepping stone to true freedom. Psychological freedom from self-imposed limitations is an essential step to freedom from relationships that are based on physical and material oppression. A mind that is imprisoned by prejudices and negative characterisations instilled in it by others is unlikely to be open to free itself from oppression. (Ramphele 2017:22-23)

Hence the need to nurture and develop agency in ordinary Africans. For as long as they expect answers to their own prayers to be parachuted to them, inside-out transformation will be minimal.

In Africa, we need active citizenship in our communities of poverty. For this active citizenship to be beneficial, it will require a motivated, 'educated and empowered citizenry' (De Beer 2008:6). The church could train and prepare its members for that (De Beer 2008:6). Kritzinger (2008:99) is optimistic in this process because he believes that there 'exists among humans because they are humans, a solidarity' to nurture thin places around them. This is the truth this article would like to share. Storytelling seems to be an appropriate vehicle to convey this message of hope. This article alludes to a few Christian activists from Soshanguve who worked in partnership with one another to make it possible for everyone's life to flourish. Such activists are Elizabeth Matsemela, Smangaliso Mkhatshwa, Benny Makena and Hans Hlalethwa (Pretoria News 2010). Elizabeth Matsemela is known as the mother of Soshanguve:

During the 1970s, her home provided a sanctuary for victims of violence and social injustices. She was a fierce advocate for equal rights for women and children. She participated in the march of women to the Union Building against the pass law in 1956. (Pretoria News 2010:4)

Smangaliso Mkhatshwa was a Roman Catholic priest who believed so much in the power of the masses that he clandestinely opened the doors of his church for community gatherings when such gatherings were banned during apartheid (1948-1994). He was a community activist. He did this in close partnership with Benny Makena, Elizabeth Matsemela and Hans Hlalethwa. They are credited with fairly distributing land to people who lived in slum communities outside and inside Soshanguve. People were relocated to the northern part of the township. These partners came from different denominations but worked closely together for the common good (Pretoria News 2010). 
These activists' sweat and blood has inspired this storytelling approach so that their legacy could be resurrected and incarnated in the lives of ordinary people. Retelling their stories remind us of kingdom-like efforts that were authored on the shores of a poor community. They assure us that building thin places is possible, even in places where poverty seems to negatively affect a flourishing life. These stories have been energy-giving as our team encourages its neighbours to author new stories of hope that would give a glimpse of a flourishing life around them.

\section{Storytelling}

Woodside et al. (2008) point out that:

[S]torytelling is pervasive through life. Much information is stored, indexed, and retrieved in the form of stories. Although lectures tend to put people to sleep, stories move them to action. People relate to each other in terms of stories. (p. 97).

The majority of black Africans live in contexts that are primarily oral in terms of how people build knowledge capital. They are raised in a world that is primarily understood 'through proverbs, stories, and relationships' (Sample 1994:3). In traditional Africa, 'proverbs and stories' were the most used vehicles to 'communicate knowledge' (Sample 1994:3). Chinua Achebe (2000) once stated that, 'proverbs are the palm oil with which words are eaten and the horse on which conversations rides'. This article uses this familiar vehicle of knowledge and wisdom acquisition to nurture agency in people. Storytelling reminds us that when our participation in making thin places comes to pass, lives flourish around us. Katongole (2011:2) stresses that, 'who we are, and who we are capable of becoming, depends very much on the stories we tell, the stories we listen to, and the stories we live'. In addition, 'stories not only shape our values, aims, and goals; they define the range of what is desirable and what is possible' (Katongole 2011:2). According to him:

$[S]$ tories are not simply fictional narratives meant for our entertainment; stories are part of our social ecology. They are embedded in us and form the very heart of our cultural, economic, religious, and political worlds. (Katongole 2011:2-3)

He adds that Africa as a continent is:

$[N]$ ot so much a place, but a story or set of stories about how people of the continent called Africa are located in the narrative that constitutes the modern world. Christian social ethics must uncover the underlying stories of the key social institutions in Africa that affect both their performance and the types of characters they produce. (Katongole 2011:2-3)

Conradie (2015:115) states that, 'we are incorrigibly cosmic storytellers. It is in the art of storytelling that the key to human knowledge resides'. In addition, he describes theology as a retelling, retrieving, reinterpreting and reenacting of the integral story of God's creative, nourishing, hurt, enduring, salvific, innovating and consummating love for the world which God has brought into being (Conradie 2015:111). Storytelling contributes immensely to a flourishing life, which is a foundational basis of thin places. This article's storytelling is inspired by Barack Obama's book Of thee I sing: A letter to my daughters. This book asks affirming questions that are key to imagining a flourishing life in a community of poverty, which is perceived as undesirable by many of its residents. These questions provided a gateway to imagine Soshanguve as a thin place. I wrote letters to my neighbours. I wrote 15 letters, picturing 15 individuals who InnerCHANGE works closely with. Each of these letters asks questions that depict these individuals' uniqueness.

Dear neighbour,

\section{'Have I told you how wonderful you are'? (Obama 2010:5)}

You are Soshanguve.

You defy the virus of separation that slavery, colonialism, tribalism, xenophobia and homophobia have spread on your shores.

The spread of this virus is like the strong signal your armpit gives you, when your body needs to be refreshed. You have intentionally chosen to pursue the beauty that the kingdom of God in its diversity, brings.

You have decided that SOthos, SHAnganis, NGUnis and VEndas must live together as one people.

Through your bold act, you affirm God's truth that all human beings were created with equal worth (Gn 1:26-30).

\section{'Have I told you that you are' resilient? (Obama 2010:6)}

Originally, all your families came from outside this township.

You faced the adversity of the apartheid government. You also faced the adversity of your next-door neighbour, the Bophuthatswana government.

You remained steadfast and kept believing that a better future was around the corner.

You wanted to be known as a loud voice that sings an alternative song.

Where apartheid was the order of the day, you chose to affirm diversity.

Where murdering was a fashion, you chose to rescue victims.

Where destruction was encouraged, you chose to carry Isaiah's legacy.

You wanted to the known as the rebuilder of houses left in ruins,

a builder and repairer of our township walls and streets (Is 58:12).

\section{'Have I told you that you are' part of a rich history? (Obama 2010)}

The history of inequality and oppression around you is a growing pain.

Some of it is like a pregnant woman's birth pain, some of it is a cancerous tumour.

Birth pain is part of a process of bringing life into existence; it is therefore necessary.

A cancerous tumour has to be removed because it is toxic to your body. 
Nelson Mandela is a good example of birth pain.

He converted his pain of spending many years in prison, as a resource and an opportunity to be a reconciler.

Many of our African politicians have displayed a type of leadership,

that is a cancerous tumour for their countries and our continent.

May you be in tune with your rich history so that you can be a birth pain where God places us.

\section{'Have I told you that you were' a star? (Obama 2010)}

Solomon Mahlangu, a young man, from the nearby township of Mamelodi, inspired the whole world.

He graciously embraced a painful death, because the cause he stood for was more important than his own life. Every time there is oppression, injustice and corruption, Salomon Mahlangu reminds you this: 'My blood will nourish the tree that will bear the fruits of freedom. Tell my people that I love them. They must continue the fight' (SBF FrankTalk 2019).

He reminds you of one of Jesus' messages to His disciples:

If any of you want to be my followers, you must forget about yourself. You must take up your cross every day and follow me. If you want to save your life, you will destroy it. But if you give up your life for me, you will save it. What will you gain, if you own the whole world but destroy yourself or waste your life? (Lk 9:23-25)

He is to the young people of this continent what Paul encouraged Timothy to be:

Don't let anyone make fun of you, just because you are young. Set an example for other followers by what you say and do, as well as by your love, faith, and purity. (1 Tm 4:12)

\section{'Have I told you that you are' authentic? (Obama 2010)}

In 1792 in Sierra Leone, a man who was proud of his culture, Samuel Ajayi Crowther,

introduced the use of his local language, Yoruba, among his own people in worship (Schroeder 2008:76).

He was so in touch with who he was created to be,

that nothing stopped him from expressing that.

You are uniquely designed to be a blessing to others and to this world.

He encourages you to be authentic and proud of your identity.

Your uniqueness is a lamp that is meant to shine and enlighten others.

Hiding that lamp under the table will unearth tears of melancholy in our society.

Your uniqueness is needed to help our land rise and shine.

\section{'Have I told you that you are courageous'? (Obama 2010)}

Our ancestors in faith such as Dona Beatriz Kimpa Vita, Simon Kimbangu, Engenas Lekganyane, Isaac Shembe and Glayton Modise rose as a voice of contextual expressions of the church.

They were the sign of alternatives.

They were the sign of what holy discontentment looks like (Huckins \& Yackley 2012).

They were the sign of rocking the boat so that the diversity of expressions is welcome.

They were the sign of the genius of imagination.

They are passing the baton to you.

They are blowing an assertive, yet gentle breeze in your ears.

They want you to know: this is your turn.

Make God relevant.

\section{'Have I told you that you are' respectful? (Obama 2010)}

You have risen above the patriarchal bias of our society, you have allowed good-hearted and minded people to influence you regardless of their gender.

Elizabeth Matsimela was a woman who walked in the dust of your streets, slept between the walls of your township and raised her family under your watchful eyes.

She decided to open her eyes in order to face injustices around her.

She decided to speak up when she saw the apartheid system torturing her neighbours.

She accepted to go to prison because she refused to collide with injustice through her silence.

In your hearts, she is a living epistle.

Through her actions, she removed the chains of her emotionally and psychologically imprisoned neighbours. Her protesting was to be the voice to her voiceless and abused neighbours.

And she was generous.

She reminds you today: 'I was just an ordinary person who learned to make an extraordinary impact'.

She is asking you: 'What about you'?

\section{'Have I told you that you are creative'? (Obama 2010)}

Lucky Lekgwathi, a former footballer, is a son who was raised in the dust of your streets.

He was able to make a living through entertainment.

He has taught us that formal school is not the only way out of poverty,

and that a focused pursuit of our gifting and talent could lead to a better quality of life.

Like him, God gave you a talent and gifting (Mt 25:1430). He expects you to multiply and make this world, a better place for all.

\section{'Have I told you that you are brave'? (Obama 2010:10)}

You have been a pioneer on different fronts.

This is difficult gifting to express in our society that seems to be comfortable with the status quo. 
You are a reformer, which can be a lonely space to live in. Reformers usually have enemies in all those who profited from the old order (Machiavelli 2008:55).

I am proud of you because you are a roaring lion in the streets of your township.

You roar sounds of peace, reconciliation and mutual support amongst your neighbours (Jr 29:1-12).

You roar sounds of solidarity so that together we can build the ruined walls of our township (Neh 2).

Your daily motto is to bring the kingdom of God 'on earth as it is in heaven' (Mt 6:9).

You are a true ambassador of Jesus.

\section{Have I told you that you are adventurous?}

In your pursuit of being a prophetic witness, I have seen you glow when your support came from your neighbours.

I have also seen you struggle when you were rejected.

It seems like societies tend to reject its cornerstones.

Jesus Christ, your mentor, was a rejected cornerstone (Ac 4:11).

Desmond Tutu was called a sell-out by some people.

Patrice Lumumba was silenced by the neo-colonialist political elite of his country.

You are not alone.

Jesus foresaw the challenges you are going through.

He told you: 'It is hard to be a prophet at home' (Mt 13:57).

He is telling you today: 'I will feel dishonoured if you are not the prophet I created you to be'!

\section{'Have I told you that you' take ownership? (Obama 2010)}

I admire your wisdom.

In many instances, you have been struck at the foot of your society (Mbembe 2017:ix).

You have boldly called out the perpetrators of injustice, you have called out the corrupted.

You have also admitted your shortcomings.

In some instances, you have been the enabler of injustice and corruption.

Your silence is sometimes the enemy of wisdom.

Your commitment to your family has impeded your task of building your society.

You have loved yourself at the expense of others.

You have confessed your participation in putting your society in ruins.

I have also seen you making bricks under the sun,

digging sand in the rain,

transporting cement on your head,

so that your township can rebuild its lost beauty.

\section{'Have I told you that you are smart'? (Obama 2010:8)}

Your ability to form relationships cross cultures is spectacular!

You are the paragon of African genius.

A genius out of which flows the capacity of Africans to inhabit several worlds at once (Mbembe 2017:102).
You have been a bridge builder.

You have been a connector.

Through your prowess, we have learned how all creatures are united to their creator.

Through your life, we have learned that rainbow is not just a collage of colour,

but it is a platform where colours have a symbiotic relationship.

\section{'Have I told you that you are strong'? (Obama 2010:16)}

You spend 3 hours on the road to get to work, Yet you find time to be an ambassador of Jesus there.

You spend 3 hours on the road from work to your house, Yet we make time to love others in your community.

You have an exceptional ability to harmonize your knowledge of God and your passion to love others through sport.

Lao Tze is very proud of you.

He founded Taoism to teach us to find the way:

To strike a good balance between the yang (knowledge) and the yin (passion) (Max-Neef 2005:10).

You exemplify such a balance.

\section{'Have I told you that you are hospitable'? (Obama 2010:18)}

Every day, many children from other townships come to knock on your doors.

You have opened your schools to educate them. People from all over the world come to live with you. You opened your arms of embrace to welcome them You are a conduit of God's blessing to others (Gn 12:1-3). You tirelessly look for opportunities to bless.

You are generous with your place and your assets.

\section{'Have I told you that you are part of a historical narrative'? (Obama 2010)}

Many people before you have contributed to what Africa is today and what Africa could be today. They warned you that 'the negation of the history and intellectual accomplishments of Black Africans was a cultural and mental murder' (Diop 1974:47).

You can learn from your fellow 'descendants of European settlers who usually draw their strengths from their history as a people group' (Ramphele 2017:52).

As you are putting yourself out there as a change agent, please remember that:

$[I] \mathrm{n}$ the face of cultural aggression of all sorts, in the face of all disintegrating factors of the outside world, the most efficient cultural weapon with which a people can arm itself is the feeling of historical continuity. (Diop 1974:54)

I plead you to hold this truth as the credo of your cultural emancipation. This is because:

The most significant damage wrought by imperial and colonial conquest was the cultural and mental murder of indigenous Africans ... The continuity that history gives to people is their most powerful weapon against attacks on their identity and self-confidence. (Ramphele 2017:55-56) 


\section{As a way forward:}

[T] he path is clear: on the basis of a critique of the past, we must create a future that is inseparable from the notions of justice, dignity, and the in-common. (Mbembe 2017:xiv)

I get the privilege of reading these letters to neighbours. I spend time with them on a weekly basis. Through the reading of these letters, I get to tell that we have a prophetic role to play in society, starting from our neighbourhood. I get to challenge them to strive not to be normal. Being normal in our communities of poverty means having dependency and entitlement mentalities, and perceiving oneself as a victim of history. These letters have been a helpful medium to teach ordinary people what it looks like to be an agent of hope. I have seen hopeful signs when individuals understand the meaning of these letters. I have seen them being catalysts of thin places where life flourishes. This article calls these individuals transformation agents.

\section{Transformation agents}

Several scholars have shaped this article understanding of who a transformation agent is. Burns (1978:4) describes transformation agents as individuals 'who generally observe principles of human dignity and worth, human rights, good social values, and individual and socio-political transformation'. According to him, they 'are able to recognise existing needs' of individuals and a community, and engage them in a way that is solution-seeking. Their engagement usually leads to new insights into ways to heal or build a community through its residents. Wong (2017) defines transformation agents as people who 'value being part of the fabric of a community and influence it from the inside out. They value being true and tangible witnesses of the gospel as good news'. They actively participate in building thin places around them. Max-Neef (2005:10) uses the Taoism paradigm of the balance between the yang and yin to explain who a transformation agent is. Taoism (Pollard, Tignor \& Clifford 2011) is 'a religious or philosophical tradition of Chinese origin which emphasizes living in harmony with the Tao (the way)'. According to Max-Neef (2005:10), a transformation agent is an incarnation of 'the way - a balance between the yang and yin'. It is an exemplary way of marrying our relational thought to rational thought. This paradigm has been helpful in our missiology. In our team, we train ourselves to attain a logic that is capable of harmonising our knowledge of God (yang) and our passion (yin). We are inspired by Addison (2009) who believes that:

$[A]$ passionate faith is at the heart of every dynamic missionary movement. It is the greatest resource. Today where Christianity is expanding rapidly in the developing world, it is often the only resource. (p. 49)

We are experimenting balancing the rational (teaching the Word of God) and the emotional (tapping into people's passion) to train our neighbours as sent out, trained to develop new eyes to be participants in the flourishing of lives around them and as midwives of thin places they call home.
Storytelling has been a helpful vehicle in catalysing this formation. Our history and current realities as black people challenge us to go the road of participating in building our communities. Mbembe (2017) points out that:

$[\mathrm{W}]$ hether in literature, philosophy, the arts, or politics, the black discourse has been dominated by three events: slavery, colonisation and apartheid. Still today, they imprison the ways in which black discourse expresses itself. (p. 19)

There is a dependency mentality that is clouding our ability to emancipate ourselves. We are well justified in complaining about the kind of gospel the coloniser imported to Africa. At the same time, we should be ashamed of ourselves for not designing alternatives that could have allowed lives to flourish on the continent. These alternatives could have created thin places throughout Africa. However, in many instances, we continue to preach Marx's (1976) saying, 'Religion is the sigh of the oppressed creature, the heart of a heartless world, and the soul of soulless conditions. It is the opium of the people'. To this day some church leaders still collide with the corrupted, demagogues, neo-colonisers and oppressors. Africa is longing to see in the near future a kind of society Hlumelo Biko (2013) describes:

Building a people-centric society characterised by its equality in opportunity granted to all citizens and thereby facilitating an era of shared prosperity through a globally competitive economy will be the greatest way Africa can honour the men and women who died fighting for its liberation. (p. 273)

In such a society, lives will flourish. Storytelling could be a creative way to help people envision such a society and be encouraged to participate in bringing it to pass. Retrieving old stories and affirming new stories to nurture agency could help. We aim to 'build ourselves into the' continent 'of our dreams' (Ramphele 2017:27). We would like to see ordinary people bring 'a new spirit of hope and accomplishment to' our communities (Stearns 2011:52) and, in addition, for that spirit to 'sweep across the continent' in sharing 'energy, self-reliance and a determination to shape' our own destinies as Africa (Stearns 2011:52). Katongole (2011) stresses that:

Christianity continues to grow and thrive in Africa, but so too grow the realities of poverty, violence, and civil war ... There are a number of reasons for these shortcomings, not least of which are deep-seated assumptions about the relationship between Christianity and the social-political sphere. One assumption is that the task of ensuring peace, democracy, and development in a word, the social and material conditions of life - properly belongs to the jurisdiction of politics. (p. 1)

This article argued that the church needs to be a participant in building Africa holistically. Such participation will lead to a flourishing life in Africa. Such a state will be a thin place for all, including non-Africans.

\section{Conclusion}

This article used the narrative approach of storytelling to contribute in a small way to the prophetic role of the church 
in society. Communities of poverty are known to be overly dependent on government to survive and thrive. This is not sustainable in the long-term. There is a necessity to raise agency from within. Addison (2009:111) stresses that, 'necessity is the mother of invention. New ideas come from fresh inventions'. This article used old and existing stories to inspire the imagination of what could be if individuals and communities were to be agents of their own hope. In this sense, this article plays the role of a prophet. Brueggemann (2001:66) points out that, 'a prophet has a purpose in bringing hope to public expression, and that is to return the community to its single referent, the sovereign faithfulness of God'. He adds that 'prophetic ministry consists of offering an alternative perception of reality and in letting people see their own history in the light of God's freedom and his will for justice' (Brueggemann 2001:116). Such a perception has the potential to orchestrate change from within, which will allow lives to flourish and birth thin places. Storytelling is a highway that could help accomplish that.

\section{Acknowledgements Competing interests}

The author has declared that no competing interests exist.

\section{Authors' contributions}

This article contributes to the area of developing and nurturing agency in ordinary people from communities of poverty. It uses the narrative approach of storytelling to recount particular past events that happened. This is used as a tool to cultivate a sense of confidence in grassroots people in participating in being the answer to their own prayers, hence becoming agents of hope. The author wrote a letter to 15 of his neighbours, communicating his desire to see a change from within.

\section{Ethical considerations}

This article followed all ethical standards for research without direct contact with human or animal subjects.

\section{Funding information}

This research received no specific grant from any funding agency in the public, commercial or not-for-profit sectors.

\section{Data availability statement}

Data sharing is not applicable to this article as no new data were created or analysed in this study.

\section{Disclaimer}

The views expressed in this article are the author's own. He did not benefit from any sources of support in writing, nor did he write this article for financial gain.

\section{References}

Achebe, C., 2000, Things fall apart, Fawcett Press, New York, NY.

Addison, S., 2009, Movements that change the world, Missional Press, Smyrna, DE.

Andrews, M., Squire, C. \& Tamboukou, M., 2013, Doing narrative research, SAGE Publications, London. https://doi.org/10.4135/9781526402271.

Biko, H., 2013, The great African society: A plan for a nation gone astray, Jonathan Ball, Cape Town.

Biko, S., 2007, 'Black consciousness and the quest for a true humanity', in C. van Wyk (ed.), We write what we like: Celebrating Steve Biko, pp. 151-163, Wits University Press, Johannesburg.

Brueggemann, W., 2001, The prophetic imagination, 2nd edn., Fortress Press, Minneapolis, MI.

Burns, J.M., 1978, Leadership, Harper \& Row, New York, NY.

Clarke, J.H., 1991, Africans at the crossroads: Notes for an African world revolution, Africa World Press, Trenton, NJ.

Conradie, E., 2015, The earth in God's economy: Creation, salvation and consummation in ecological perspective, Studies in Religion and the Environment vol. 10, LIT Verlag, Zürich.

Conradie, E.M., 2009, 'Towards a theology of place in the South African context: Some reflections from the perspective of Ecotheology', Religion and Theology 16(1-2), reflections from the perspective of Ecotheology', R
3-18. https://doi.org/10.1163/156973109X449967

De Beer, S., 2008, 'Recovering black consciousness for new and universal struggles' in C.W. du Toit (ed.), The legacy of Stephen Bantu Biko: Theological challenges, Research Institute for Theology and Religion, University of South Africa, Pretoria.

Diop, C.A., 1974, The African origin of civilization: Myth or reality, Lawrence Hill, New York, NY.

Fitch, D.E., 2016, Faithful presence: Seven disciplines that shape the church for mission, InterVarsity Press, Downers Grove, IL.

Hayes, J.B., 2006, Sub-merge: Living deep in a shallow world: Service, justice and contemplation among the world's poor, Regal, Ventura, CA.

Holy Bible, Contemporary English Version (CEV), 1995, American Bible Society, Philadelphia, PA.

Holy Bible, New International Version (NIV), 2011, Biblica, Inc., Colorado Springs, CO.

Huckins, J. \& Yackley, R., 2012, Thin places: 6 postures for creating \& practicing missional community, The House Studio, Kansas City, MO.

Katongole, E., 2011, The sacrifice of Africa: A political theology for Africa, William B. Eerdmans, Grand Rapids, MI.

Katongole, E., 2017, Born from lament: The theology and politics of hope in Africa William B. Eerdmans, Grand Rapids, MI.

Keum, J. (ed.), 2013, Together towards life: Mission and evangelism in changing landscapes: With a practical guide, World Council of Churches Publications, Geneva.

Kritzinger, J.N.J., 2008, 'Liberating whiteness: Engaging with the anti-racist dialectics of Steve Biko', in C.W. du Toit (ed.), The legacy of Stephen Bantu Biko: Theological of Steve Biko, in C.W. du Toit (ed.), The legacy of Stephen Bantu Biko: Theological
challenges, Research Institute for Theology and Religion, University of challenges, Research
South Africa, Pretoria.

Machiavelli, N., 2008, The prince, Hackett, Indianapolis, IN.

Marx, K., 1976, Introduction to a contribution to the critique of Hegel's philosophy of right, Collected Works, vol. 3, Cambridge University Press, New York, NY.

Max-Neef, M.A., 2005, 'Foundations of transdisciplinarity', Ecological Economics 53(1), 5-16. https://doi.org/10.1016/j.ecolecon.2005.01.014

Mbembe, A., 2017, Critique of black reason, transl. introduction by L. Dubois, Duke University Press, Durham, NC.

Muhindo, M.F., 2018, 'Pas de president', viewed 21 April 2019, from https:// soundcloud.com/lucha-rdcongo/pas-de-president-chanson-par-muhindomasimengo-fabrice-alias-fb-faba.

Mwambazambi, K. \& Banza, A.K., 2014, 'Developing transformational leadership for Sub-Saharan Africa: Essential missiological considerations for Church workers', Verbum et Ecclesia 35(1), 9, Art. \#849. http://doi.org/10.4102/ ve.v35i1.849

Niemandt, C.J.P., 2016, 'Rediscovering joy in costly and radical discipleship in mission', HTS Teologiese Studies/Theological Studies 72(4), a3831. http://doi.org/10.4102/ hts.v72i4.3831

Obama, B., 2010, Of thee I sing: A letter to my daughters, Knopf, New York, NY.

Polit, D.F. \& Beck, C.T., 2008, Nursing research: Generating and assessing evidence for nursing practice, 8th edn., Wolters Kluwer Health/Lippincott Williams \& Wilkins, Philadelphia, PA.

Pollard, R., Tignor, E. \& Clifford, R., 2011, Worlds together, worlds apart, Norton, New York, NY.

Pretoria News, October 2010, viewed 04 May 2019, from https://www.pressreader.com. Ramphele, M., 2017, Dreams, betrayal and hope, Penguin, Cape Town.

Sample, T., 1994, Ministry in an oral culture: Living with Will Rogers, Uncle Remus and Minnie Pearl, Westminster/John Knox Press, Louisville, KY.

SBF FrankTalk, 2019, 'Solomon Mahlangu: My blood will nourish the three that will bear the fruits of freedom', viewed 26 February 2019, from http://sbffranktalk. blogspot.com/2013/04/solomon-mahlangu-my-blood-will-nourish.html.

Schroeder, R.P., 2008, What is the mission of the church? A guide for Catholics, Orbis, New York, NY. 
Stearns, J.K., 2011, Dancing in the glory of monsters: The collapse of the Congo and the great war of Africa, Public Affairs, New York, NY.

Thin Places Tour, 2018, 'What are thin places?', viewed 02 November 2018, from https://thinplacestour.com/what-are-thin-places/.

Van der Merwe, I.J., 2015, 'Happiness - A primer for theological engagement', Stellenbosch Theological Journal 1(1), 291-319.

Volf, M., 2015, Flourishing: Why we need religion in a globalized world, Kindle edn., Yale University Press, New Haven, CT.
Volf, M. \& Croasmun, M., 2019, For the life of the world: Theology that makes a difference, Brazos Press, Grand Rapids, MI.

Wine, B., 2017, 'Freedom', viewed 03 April 2019, from https://www.youtube.com/wa tch?v=8g0W9CIY5iM\&feature=share

Wong, P., 2017, 'How best to prepare missional leaders', viewed 31 July 2018, from http://www.drpaulwong.com/how-best-to-prepare-missional-leaders/.

Woodside, A.G., Sood, S. \& Miller, K.E., 2008, 'When consumers and brands talk: Storytelling theory and research in psychology and marketing', Psychology \&
Marketing 25(2), 97-145. https://doi.org/10.1002/mar.20203 